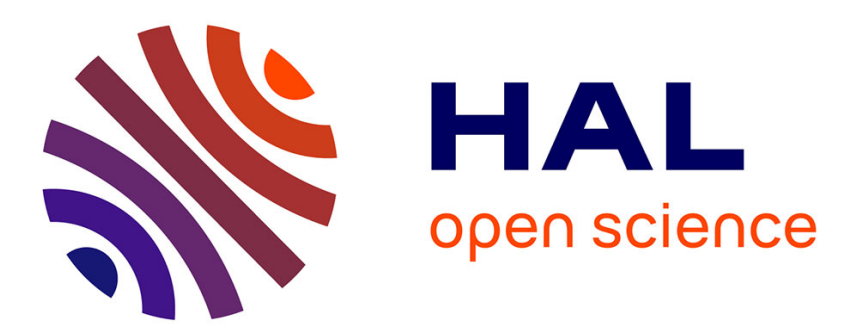

\title{
An efficient Nb-modified BiVO4 film for photo-induced bacterial inactivation and photocatalytic removal of organic pollutants
}

Olivier Monfort, Ewa Dworniczek, Leonid Satrapinskyy, Alicja Seniuk, Daniela Nyblova, Gustav Plesch

\section{To cite this version:}

Olivier Monfort, Ewa Dworniczek, Leonid Satrapinskyy, Alicja Seniuk, Daniela Nyblova, et al.. An efficient Nb-modified BiVO4 film for photo-induced bacterial inactivation and photocatalytic removal of organic pollutants. New Journal of Chemistry, 2018, 42 (8), pp.5664-5667. 10.1039/c8nj01069b . hal-01807089

HAL Id: hal-01807089

https://hal-univ-rennes1.archives-ouvertes.fr/hal-01807089

Submitted on 19 Jul 2018

HAL is a multi-disciplinary open access archive for the deposit and dissemination of scientific research documents, whether they are published or not. The documents may come from teaching and research institutions in France or abroad, or from public or private research centers.
L'archive ouverte pluridisciplinaire HAL, est destinée au dépôt et à la diffusion de documents scientifiques de niveau recherche, publiés ou non, émanant des établissements d'enseignement et de recherche français ou étrangers, des laboratoires publics ou privés. 


\title{
Efficient $\mathrm{Nb}$-modified $\mathrm{BiVO}_{4}$ film for photo-induced bacterial inactivation and photocatalytic removal of organic pollutant
}

Olivier Monfort, ${ }^{* \mathrm{ab}}$ Ewa Dworniczek, ${ }^{\mathrm{c}}$ Leonid Satrapinskyy, ${ }^{\mathrm{d}}$ Alicja Seniuk, ${ }^{\mathrm{c}}$ Daniela Nyblova ${ }^{\mathrm{a}}$ and Gustav Plesch $^{a}$

${ }^{a}$ Comenius University in Bratislava, Faculty of Natural Sciences, Department of Inorganic Chemistry, 84215 Bratislava, Slovakia

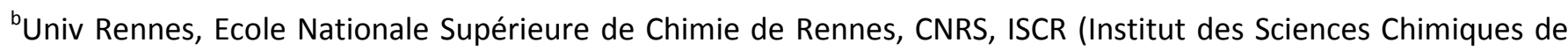
rennes) - UMR 6226, F-35000 Rennes, France

${ }^{c}$ Wroclaw Medical University, Department of Microbiology, 50368 Wroclaw, Poland

${ }^{d}$ Comenius University in Bratislava, Faculty of Natural Sciences, Department of Comenius University in Bratislava, Faculty of Mathematics Physics and Informatics, Department of Experimental Physics, 84248 Bratislava, Slovakia.

*Correspondence: olivier.monfort@ensc-rennes.fr

\begin{abstract}
Using $\mathrm{Nb}$-modified $\mathrm{BiVO}_{4}$ film, the photo-induced properties in Methicillin-resistant Staphylococcus aureus (MRSA) inactivation under simulated solar light reached $43 \%$ after 1 hour irradiation while $72 \%$

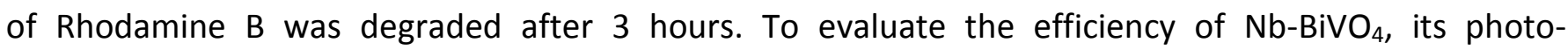
performance was compared with that of $\mathrm{BiVO}_{4} / \mathrm{TiO}_{2}$ composites and pure $\mathrm{BiVO}_{4}$.
\end{abstract}

\section{Introduction}

Bismuth vanadate $\left(\mathrm{BiVO}_{4}\right)$ is a promising solar-light driven photocatalyst which exhibits energy band gap at $2.4 \mathrm{eV}^{1,2}$ For this reason $\mathrm{BiVO}_{4}$ materials, and more generally Bi-based oxide materials, are intensively studied for photodegradation of organic pollutant and photoproduction of $\mathrm{O}_{2}$ by water splitting. ${ }^{1-6}$ However $\mathrm{BiVO}_{4}$ photocatalyst exhibits high recombination rate of electron-hole pairs that limits its performance. ${ }^{1,2}$ Therefore it is necessary to modify $\mathrm{BiVO}_{4}$ photocatalyst to increase its efficiency in photochemical processes by designing doped or composite systems. ${ }^{1,2}$ Modification using silver or carbon-based materials can be cited. ${ }^{3-6}$

On the other hand, $\mathrm{BiVO}_{4}$-based photocatalysts are mainly studied in the form of powder suspensions ${ }^{7-10}$ rather than supported systems ${ }^{11-15}$ for photo-oxidative degradation of organic pollutant. Supported systems such as films are more practical for obvious reason: the readily post-separation of the photocatalyst with the polluted media. ${ }^{16}$ Different photocatalytic mechanisms were reported according to the way of $\mathrm{BiVO}_{4}$ modification. Indeed variously doped and numerous $\mathrm{BiVO}_{4}$ composite systems could 
exhibit either photogenerated holes or radicals as main oxidative species..$^{3-11,15}$ In addition, among the works devoted to photo-induced antimicrobial properties of bismuth vanadate-based materials, most of them are focused on E. coli inactivation. ${ }^{17-26}$

In this work, bismuth vanadate films are prepared by metal organic decomposition and modified using niobium(V) and $\mathrm{TiO}_{2}$. The photocatalytic efficiency in Rhodamine $\mathrm{B}$ degradation was compared using different $\mathrm{BiVO}_{4}$-based films and the study of inactivation of MRSA strain is, for the first time, demonstrated under solar-like irradiation. MRSA (Methicillin-resistant Staphylococcus aureus) are chosen in this study because such bacteria are clinically important and more resistant than $E$. coli bacterial strains. Indeed, the Staphylococcus aureus is the most common bacterial pathogen worldwide. $^{27}$ Its methicillin-resistant variants (MRSA) generate serious concern over the loss of antibiotics susceptibility. ${ }^{27}$ The observed photo-induced properties as well as mechanisms are also discussed here, especially for $\mathrm{Nb}$-modified $\mathrm{BiVO}_{4}$. Such photocatalytic films could find promising environmental applications but also could be developed for clinical or food technology.

\section{Experimental}

Pure bismuth vanadate films were prepared using a precursor solution based on vanadium(IV)

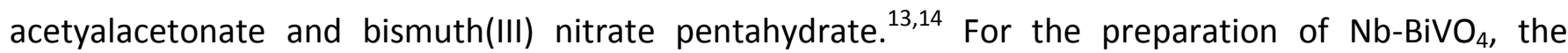
precursor solution was modified by 10 at\% of $\mathrm{Nb}(\mathrm{V})$ chloride while $\mathrm{BiVO}_{4} / \mathrm{TiO}_{2}$ composites were prepared using the $\mathrm{BiVO}_{4}$ precursor solution and $\mathrm{TiO}_{2}$ sol-gel. ${ }^{13,14}$ Films were deposited using doctor blade method by casting the precursor solution between Scotch ${ }^{\circledR}$ tape using glass Pasteur pipette on $\mathrm{Si} / \mathrm{SiO}_{2}$ substrates. Crystalline films were obtained after subsequent metal organic decomposition at $500^{\circ} \mathrm{C}$ for 5 minutes. For the composites, two different layered configurations were designed: top coated-BiVO 4 over $\mathrm{TiO}_{2}$ (top- $\mathrm{BiVO}_{4} / \mathrm{TiO}_{2}$ ) and top coated-TiO ${ }_{2}$ over $\mathrm{BiVO}_{4}$ (top- $-\mathrm{TiO}_{2} / \mathrm{BiVO}_{4}$ ). The films were approximatively $1 \mu \mathrm{m}$ thick.

The composition of crystalline phases in the films was analyzed by X-ray diffraction using PANalytical XPert Pro MRD diffractometer. The surface morphology was characterized by scanning electron microscopy using Tescan Lyra III. The energy band gap was evaluated by diffuse reflectance spectroscopy using Shimadzu model 2600 spectrophotometer.

Photocatalytic experiments were performed for 180 minutes under solar-like irradiation using a Bclass solar simulator with spectral characteristics similar to natural sunlight (HQI TS - OSRAM 400 W; $\lambda_{\max }=525 \mathrm{~nm}$ ) where the decolorization of $10^{-5} \mathrm{M}$ Rhodamine $\mathrm{B}(\mathrm{RhB})$ solution was followed by UV-vis 
spectrophotometer (Jasco V-530). The mechanism of photooxidative degradation was determined indirectly using charge scavengers of the different species possibly involved: ammonium oxalate for photogenerated holes $\left(\mathrm{h}^{+}\right)$, iso-propanol for hydroxyl radicals $\left(\mathrm{OH}^{*}\right)$ and $\mathrm{p}$-benzoquinone for superoxide radicals $\left(\mathrm{O}_{2}{ }^{\circ}\right)$. The experiments were performed in triplicates.

To evaluate the antimicrobial effectiveness at the surface of the samples, modified JIS Z 2801: 2010 test method, was used. Briefly, $100 \mu \mathrm{L}$ of MRSA K324 which represents (at $t=0 \mathrm{~min}$ ) $3 \cdot 10^{5} \mathrm{CFU} / \mathrm{mL}$ (Colony Forming Unit) was instilled onto each $\mathrm{BiVO}_{4}$-based film $\left(1 \mathrm{~cm}^{2}\right)$ kept in a humid atmosphere to avoid extensive drying of the suspension and irradiated for $30 \mathrm{~min}$ and $60 \mathrm{~min}$ (Xenon lamp - 15 $\mathrm{mW} / \mathrm{cm}^{2}$ ). Control experiments were carried out in the dark, under the same conditions. At appropriate time, the test bacteria were washed out with sterile saline solution, to release the inoculum from the surface. Quantification of the viable cells was performed by a standard plating method and incubation at $37^{\circ} \mathrm{C}$ for $24-48 \mathrm{~h}$. Bactericidal activity of the samples was evaluated using logarithmic reduction of number of microbial cells. Each antimicrobial test was performed in duplicate.

\section{Results and discussion}

The crystalline phase composition of freshly prepared materials is analyzed by XRD (Electronic Supplementary Information). All the photocatalysts exhibit crystalline monoclinic scheelite $\mathrm{BiVO}_{4}$

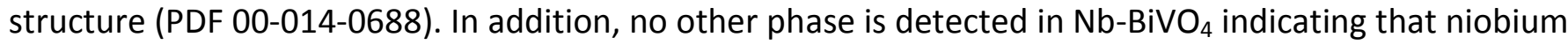
is probably present in the form of oxide either amorphous or at nanosize level. This observation is confirmed by EDX (Energy Dispersive X-ray Spectroscopy) measurement which detected niobium in $\mathrm{Nb}$ $\mathrm{BiVO}_{4}$ sample. Both $\mathrm{BiVO}_{4} / \mathrm{TiO}_{2}$ composites exhibit additional anatase phase (PDF 00-021-1272). The energy band gap of pure and $\mathrm{Nb}$-modified $\mathrm{BiVO}_{4}$ is evaluated at $2.4 \mathrm{eV}$ approximatively for both materials by using the Tauc's method, i.e. they absorb light in the visible region (at $\lambda \leq 500 \mathrm{~nm}$ ). However, the composites exhibited a blue shift in the energy band gap ( $2.5 \mathrm{eV}$ ) due to screening effect of $\mathrm{TiO}_{2}$ that is absorbing only in the UV region.

Strong differences appear in the morphology of film surface. In Fig. 1, it is clear that Nb-BiVO (Fig. $^{2}$ 1c) exhibits a porous surface morphology presenting a hierarchical structure while pristine and composite samples (Fig. 1a,b) have a more dense and homogeneous surface. Concerning the both composites, top-BiVO $4 / \mathrm{TiO}_{2}$ sample exhibits similar morphology than pure $\mathrm{BiVO}_{4}$ (Fig. 1a) while top$\mathrm{TiO}_{2} / \mathrm{BiVO}_{4}$ has similar surface than pure $\mathrm{TiO}_{2}$ (Fig. 1b). 




Figure 1. Surface morphology of (a) pristine $\mathrm{BiVO}_{4}$ and (inset) top-coated $\mathrm{BiVO}_{4}$ over $\mathrm{TiO}_{2}$ composite, (b) pure $\mathrm{TiO}{ }_{2}$ and (inset) top-coated $\mathrm{TiO}_{2}$ over $\mathrm{BiVO}_{4}$ composite and (c) $\mathrm{Nb}_{-}-\mathrm{BiVO}_{4}$.

The photocatalytic degradation of RhB was followed under simulated solar irradiation and the corresponding degradation rates are presented in Fig. 2. It is worth to notice that the photocatalysts remain intact after their use since XRD patterns did not change (Electronic Supplementary Information). Comparing the tested photocatalysts, $\mathrm{Nb}-\mathrm{BiVO}_{4}$ exhibits the best photodegradation efficiency with a removal of $72 \%$ of $\mathrm{RhB}$ after 180 min irradiation. Such performance is due to the beneficial morphology of the film surface that exhibits high porosity and thus higher active surface area than the other materials (Fig. 1). Both composites exhibit also excellent photoxidative properties by degrading from 56 to $61 \%$ of pollutants which is better than the single components (Fig. 2a). It means that composites are constituted of efficient heterojunction between titania and bismuth vanadate that improves electronhole pair separation and transport within the material: photogenerated $\mathrm{e}^{-}$are accumulated in $\mathrm{TiO}_{2}$ while $\mathrm{h}^{+}$are concentrated in $\mathrm{BiVO}_{4}{ }^{13}$ It is also noteworthy that top- $\mathrm{TiO}_{2} / \mathrm{BiVO}_{4}$ is more efficient than top$\mathrm{BiVO}_{4} / \mathrm{TiO}_{2}$ (Fig. 2a). The photocatalytic mechanism was evaluated using different charge carriers (Fig. $2 b)$.
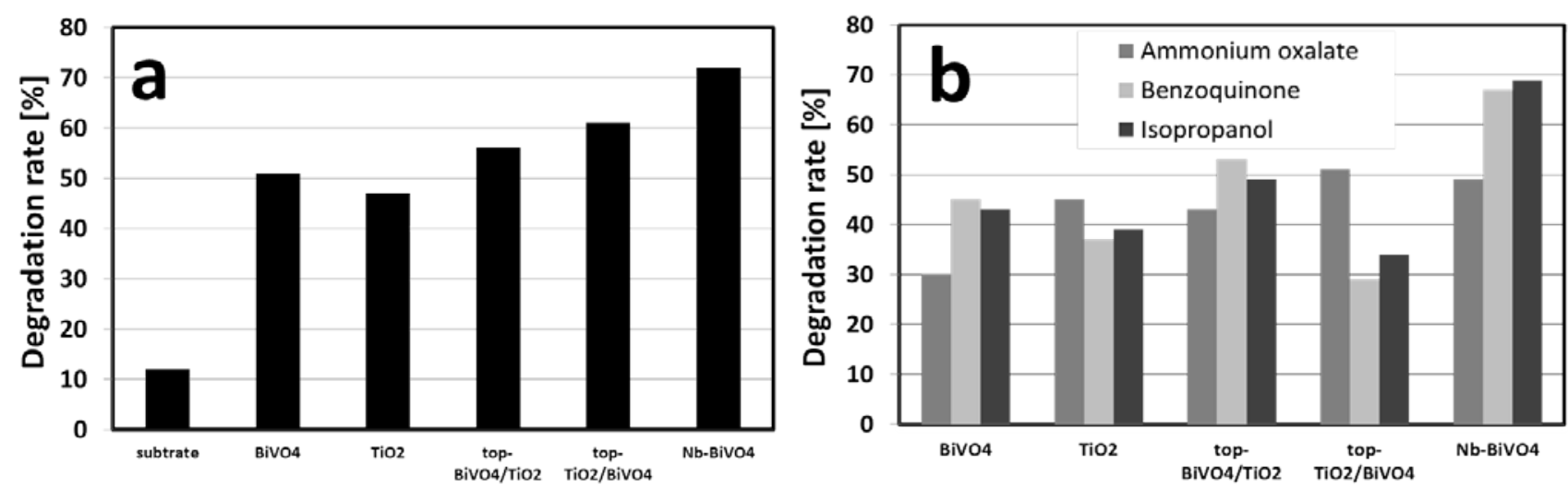

Figure 2. (a) Degradation rates of RhB after 180 min irradiation under solar-like light and (b) the corresponding effects of charge scavengers on the removal efficiencies of RhB. 
It is obvious that photocatalytic degradation proceeds mainly through photogenerated holes using films exhibiting $\mathrm{BiVO}_{4}$-based material at their surface (i.e. pristine $\mathrm{BiVO}_{4}, \mathrm{Nb}-\mathrm{BiVO}_{4}$ and top-BiVO $4 / \mathrm{TiO}_{2}$ composite) while films with titania at the surface oxidize essentially through superoxide and hydroxyl radicals. Indeed, the photocatalytic activity of top- $\mathrm{TiO}_{2} / \mathrm{BiVO}_{4}$ and pure $\mathrm{TiO}_{2}$ is strongly inhibited in presence of $\mathrm{O}_{2}{ }^{\circ-}$ and $\mathrm{OH}^{\bullet}$ scavengers indicating that they are the main oxidative species (Fig. 2b). Similarly, the other photocatalysts show a strong decrease in photooxidative degradation rate of RhB in presence of ammonium oxalate which are thus the main reactive species in this case (Fig. 2b).

The antimicrobial properties of $\mathrm{BiVO}_{4}$-based films are summarized in Fig. 3 after simulated solar irradiation and in the dark. It is clear that in absence of light, the series of $\mathrm{BiVO}_{4}$-based photocatalysts are not able to inactivate the MRSA strain (Fig. 3a). There is also no photolysis of bacterial cells under irradiation alone. Under our conditions, $30 \mathrm{~min}$ irradiation time is too short to put in evidence any

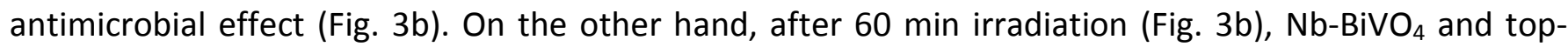
$\mathrm{BiVO}_{4} / \mathrm{TiO}_{2}$ composite exhibit significant photo-induced antimicrobial properties (43 and $39 \%$ inactivation, respectively) while the remaining samples show poor bactericidal activity. It is remarkable that, in case of top- $\mathrm{TiO}_{2} / \mathrm{BiVO}_{4}$ composite, only weak photo-disinficient properties are observed although this composite has good photooxidative power with the production of superoxide and hydroxyl radicals. So far, we cannot explain this observation. But it could be assumed that inactivation of the bacterial strains depends not only on the degradation mechanism but also on other factors related to the bacterial cell such as its wall structure. Thus it is probable that the affinity of MRSA is higher toward $\mathrm{BiVO}_{4}$ surface than titania surface.
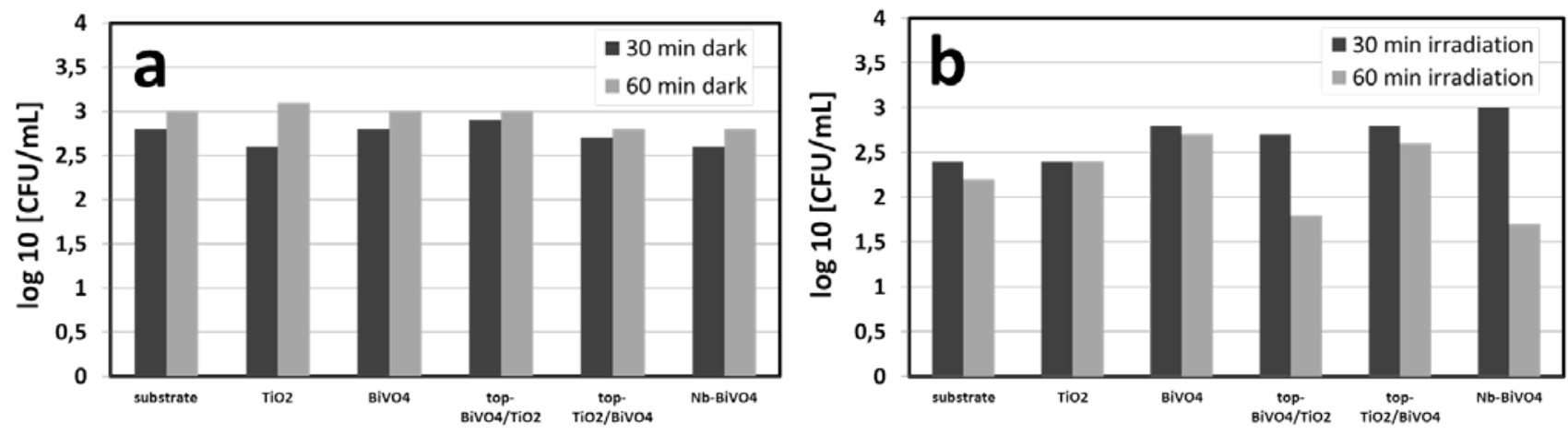

Figure 3. Survival of MRSA strain on the different $\mathrm{BiVO}_{4}$-based materials (a) in the dark, (b) after 30 and $60 \mathrm{~min}$ solar-like irradiation.

In our case, the two antimicrobial active samples $\left(\mathrm{Nb}-\mathrm{BiVO}_{4}\right.$ and top- $\left.\mathrm{BiVO}_{4} / \mathrm{TiO}_{2}\right)$ exhibit a photocatalytic power through holes and their bactericidal activity improves by the fact that (1) $\mathrm{Nb}-\mathrm{BiVO}_{4}$ film exhibits porous structure with high surface area (Fig. 1c) and (2) top- $\mathrm{BiVO}_{4} / \mathrm{TiO}_{2}$ composite has 
improved electron-hole pair separation giving rise to increased lifetime of holes. ${ }^{14}$ In addition it has been reported that photogenerated holes from $\mathrm{BiVO}_{4}$ can act as efficient oxidative agents toward bacterial cells if close contact between the photocatalyst and the bacteria is achieved. ${ }^{18,23,24}$ Therefore from the above discussion, it could be assumed that the high antimicrobial activity of $\mathrm{Nb}-\mathrm{BiVO}_{4}$ is the result of fullfilled conditions for an efficient attack of the cell membrane by photogenerated holes: high surface area combined with good affinity of MRSA at bismuth vanadate photocatalyst surface.

\section{Conclusion}

Different supported $\mathrm{BiVO}_{4}$-based materials in the form of films were tested in both the photocatalytic degradation of RhB and the inactivation of MRSA strain under simulated solar irradiation. It was found that the best material was $\mathrm{Nb}^{-\mathrm{BiVO}_{4}}$ due to its beneficial morphology which results in high degradation of pollutant and substantial bacterial inactivation. The mechanism of photo-induced properties using $\mathrm{Nb}-\mathrm{BiVO}_{4}$ involved directly the photogenerated holes. It is the first time that both photocatalytic and antimicrobial activities of different supported $\mathrm{BiVO}_{4}$ systems are simultaneously reported under the same conditions, especially for the inactivation of clinically important MRSA which achieves here $43 \%$ in presence of $\mathrm{Nb}$-modified $\mathrm{BiVO}_{4}$.

\section{Conflicts of interest}

There are no conflicts to declare.

\section{Acknowledgements}

Authors wish to acknowledge the financial supports granted by the Scientific Grant Agency of the Slovak Republic and the Statutory Research of the Wroclaw Medical University through the projects VEGA 1/0276/15 and ST.A130.16.032, respectively. Authors gratefully thank Tomas Roch for XRD measurements. This work was also supported by the Research and Development Operational Program funded by the ERDF (project ITMS:26240220027).

\section{References}

1 Y. Park, K.J. McDonald and K.S. Choi, Chemical Society Reviews, 2013, 42, 2321.

2 K.R. Tolod, S. Hernandez and N. Russo, Catalysts, 2017, 7, 13.

3 X. Lin, D. Xu, Y. Xi, R. Zhao, L. Zhao, M. Song, H. Zhai, G. Che and L. Chang, Colloids and Surfaces A: Physicochemical and Engineering Aspects, 2017, 513, 117-124.

4 X. Lin, Y. Xi, R. Zhao, J. Shi and N. Yan, RSC Advances, 2017, 7, 53847-53854. 
5 X. Lin, D. Xu, S. Jiang, F. Xie, M. Song, H. Zhai, L. Zhao, G. Che and L. Chang, Catalysis Communications, 2017, 89, 96-99.

6 X. Lin, D. Xu, R. Zhao, Y. Xi, L. Zhao, M. Song, H. Zhai, G. Che and L. Chang, Separation and Purification Technology, 2017, 178, 163-168.

7 Y. Kanigaridou, A. Petala, Z. Frontistis, M. Antonopoulou, M. Solakidou, I. Konstantinou, Y. Deligiannakis, D. Mantzavinos and D.I. Kondarides, Chemical Engineering Journal, 2017, 318, 39.

8 Y. Liu, J. Kong, J. Yuan, W. Zhao, X. Zhu, C. Sun and J. Xie, Chemical Engineering Journal, $2018,331,242$.

9 T. Saison, N. Chemin, C. Chaneac, O. Durupthy, L. Mariey, F. Mauge, V. Brezova and J.P. Jolivet, Journal of Physical Chemistry, 2015, 119, 12967.

10 K. Zhang, Y. Liu, J. Deng, S. Xie, X. Zhao, J. Yang, Z. Han and H. Dai, Applied Catalysis B: Environmental, 2018, 224, 350.

11 T. Huo, X. Zhang, X. Dong, X. Zhang, C. Ma, G. Wang, H. Ma and M. Xue, Journal of Materials Chemistry A, 2014, 2, 17366.

12 U. Lamdab, K. Wetchakun, S. Phanichphant, W. Kangwansupamonkon and N. Wetchakun, Catalysis Today, 2016, 278, 291.

13 O. Monfort, T. Roch, M. Gregor, L. Satrapinskyy, D. Raptis, P. Lianos and G. Plesch, Journal of Environmental Chemical Engineering, 2017, 5, 5143.

14 O. Monfort, S. Sfaelou, L. Satrapinskyy, T. Plecenik, T. Roch, G. Plesch and P. Lianos, Catalysis Today, 2017, 280, 51.

15 G. Odling, and N. Robertson, ChemPhysChem, 2016, 17, 2872.

16 A.O. Ibhadon and P. Fitzpatrick, Catalysts, 2013, 3, 189.

17 C. Adan, J. Marugan, S. Obregon and G. Colon, Applied Catalysis A: General, 2016, 526, 126.

18 C. Adan, J. Marugan, S. Obregon and G. Colon, Catalysis Today, 2015, $240,93$.

19 A.Y. Booshehri, S.C.K. Goh, J. Hong, R. Jiang and R. Xu, Journal of Materials Chemistry A, $2014,2,6209$.

20 P. Ganguly, C. Byrne, A. Breen and S.C. Pillai, Applied Catalysis B: Environmental, $2018,225,51$.

21 C.K. Huang, T. Wu, C.W. Huang, C.Y. Lai, M.Y. Wu and Y.W. Lin, Applied Surface Science, $2017,399,10$.

22 C. Regmi, Y.K. Kshetri, T.H. Kim, R.P. Pandey and S.W. Lee, Molecular Catalysis, 2017, 432, 220.

23 R. Sharma, Uma, S. Singh, A. Verma and M. Khanuja, Journal of Photochemistry and Photobiology B: Biology, 2016, 162, 266.

24 W. Wang, Y. Yu, T. An, G. Li, H.Y. Yip, J.C. Yu and P.K. Wong, Environmental Science \& Technology, 2012, 46, 4599.

25 Z. Xiang, Y. Wang, P. Ju, Y. Long and D. Zhang, Journal of Alloys and Compounds, 2017, 721, 622.

26 Z. Xiang, Y. Wang, D. Zhang and P. Ju, Journal of Industrial and Engineering Chemistry, $2016,40,83$.

27 S.J. Dancer, Lancet Infectious Diseases, 2008, 8, 101. 